\title{
Hubungan Pemberian ASI Eksklusif Dan Status Gizi Ibu Dengan Pertumbuhan Lingkar Kepala Bayi Usia 6 Bulan
}

\section{Relationship among Exclusive Breastfeeding and Maternal Nutritional Status with the Growth of Head Circumference}

Ivanda Glanny Anindya*, Harsono Salimo, Yulia Lanti Retno Dewi

ABSTRAK

Latar Belakang: Pengukuran lingkar kepala sangat penting selama tahun awal kehidupan, hal ini merupakan parameter antropometri yang sangat berkorelasi dengan ukuran otak. Terjadi penyimpangan pada lingkar kepala, maka memperingatkan perkembangan otak yang tidak normal. Air susu ibu merupakan penyedia nutrisi ideal yang dibutuhkan bayi untuk pertumbuhan yang sehat secara optimal. Ibu menyusui dengan pemenuhan gizi yang baik akan mempengaruhi status gizinya. Status gizi tersebut akan menentukan kuantitas dan kualitas produk susu yang secara tidak langsung berperan dalam menentukan status gizi anak.

Tujuan : Menganalisis hubungan pemberian ASI eksklusif dan status gizi ibu dengan pertumbuhan lingkar kepala bayi usia 6 bulan.

Metode: Menggunakan desain cross-sectional di wilayah Kecamatan Kaliwates, Kabupaten Jember. Subjek penelitian adalah bayi usia 6 bulan, 128 bayi dipilih dengan purposive sampling. Data status gizi ibu berdasarkan IMT. Data pemberian ASI eksklusif berdasarkan wawancara dan data KMS. Data lingkar kepala bayi berdasarkan pengukuran langsung dan diinterprestasikan menggunakan grafik pertumbuhan WHO. Analisis data menggunakan uji Chi-Square.

Hasil : Hasil penelitian menunjukkan bahwa ada hubungan yang bermakna antara pemberian ASI eksklusif $(p<0,001)$ dan status gizi ibu $(p=0,028)$ dengan pertumbuhan lingkar kepala bayi.

Kesimpulan: Pemberian ASI eksklusif dan status gizi ibu menyusui berhubungan dengan pertumbuhan lingkar kepala bayi.

Kata kunci: status gizi, ASI eksklusif, lingkar kepala

\section{ABSTRACT}

Background: Measurement of head circumference is highly crucial during the early years of life which considered as an anthropometric parameter substantially correlated with brain size. The emergence of head circumference aberration functions to warn of abnormal brain development. Breast milk is the ideal nutritional provider that babies need for optimal healthy growth. Nursing mothers with good nutrition will affect their nutritional status. The nutritional status will determine the quantity and quality of dairy products that indirectly play a role in determining children's nutritional status.

Objective: Analyzing the relationship between exclusive breastfeeding and maternal nutritional status with the growth of the head circumference of 6 months old infants.

Method: Using a cross-sectional design in the Kaliwates, Jember. Subjects were 6 months old infants in which 128 babies were selected by purposive sampling. Data on maternal nutritional status were based on Body Mass Index (BMI). Data on exclusive breastfeeding were based on interviews and KMS data. The baby's head circumference data were based on direct measurements and those were interpreted using WHO growth charts. Then, the data were analyzed using Chi-Square test. Results: The results showed that there was a significant relationship between exclusive breastfeeding $(p<0.001)$ and maternal nutritional status ( $p=0.028$ ) with the growth of the baby's head circumference.

Conclusion: Exclusive breastfeeding and maternal nutritional status are associated with the growth of the baby's head circumference.

Keywords: nutritional status, exclusive breastfeeding, head circumference

\footnotetext{
*Koresponden :

ivandaaglanny@gmail.com
}

${ }^{1}$ Program Magister IImu Gizi Universitas Sebelas Maret, JL. Ir. Sutami 36A, 57126, Kentingan, Jebres, Surakarta, Jawa Tengah 


\section{PENDAHULUAN}

Malnutrisi adalah salah satu masalah kesehatan terbesar masa kanak-kanak di Negara berkembang ${ }^{1}$. Malnutrisi akan merubah morfologis penting di otak yang dapat merusak potensi intelektual dan menyebabkan ukuran otak lebih kecil, hal ini dikaitkan dengan ukuran lingkar kepala ${ }^{2}$. Pengukuran lingkar kepala sangat penting selama tahun pertama kehidupan, hal tersebut merupakan parameter antorpometri yang sangat berkorelasi dengan ukuran otak dan tulang tengkorak. Terjadi penyimpangan pada lingkar kepala akan memperingatkan perkembangan otak yang tidak normal ${ }^{3}$. Pengukuran lingkar kepala juga dapat menjadi deteksi dini seperti terjadinya keterlambatan perkembangan psikomotorik ${ }^{4}$, perkembangan kognitif pra-sekolah ${ }^{5}$, stunting ${ }^{6}$, hidrosefalus, tumor intrakranial dan patologi kronis lainya ${ }^{7}$. Namun, pengukuran lingkar kepala tidak dilakukan secara teratur atau dihilangkan di banyak Negara berkembang ${ }^{8}$.

Ukuran lingkar kepala selain dipengaruhi dari sosial ekonomi rendah ${ }^{9}$, keturunan dan suku bangsa, salah satu faktor pentingnya yaitu keadaan gizi ${ }^{10}$, sehingga penting memperhatikan pola pemberian makan bayi selama periode 1000 HPK dimulai dari konsepsi hingga tahun ke dua yang memiliki pengaruh signifikan terhadap pertumbuhan anak ${ }^{11}$. Terdapat penelitian di Belanda yang menyatakan bahwa pemberian ASI eksklusif dibandingkan dengan bayi yang tidak pernah disusui atau dibantu susu formula memberikan pengaruh signifikan terhadap perkembangan otak lebih matang dan pertumbuhan lingkar kepala normal12.

WHO memberikan rekomendasi untuk pemberian ASI eksklusif selama 6 bulan awal kehidupan. Pemberian ASI yang merupakan nutrisi sempurna sangat dibutuhkan untuk pertumbuhan, perkembangan otak serta meningkatkan $\mathrm{IQ}^{13,14}$. Kuantitas dan kualitas produk susu dipengaruhi oleh status gizi ibu yang secara tidak langsung berperan dalam menentukan status gizi $a a^{15}$. Oleh karena itu penting memperhatikan status gizi ibu karena mempengaruhi lama pemberian ASI eksklusif dan pertumbuhan bayi ${ }^{16}$.

Berdasarkan tingkat global pada angka cakupan ASI eksklusif masih sebesar 30\%. Cakupan tersebut belum sesuai target WHO 2025 paling sedikit $50 \%$ tingkat pemberian ASI eksklusif dalam 6 bulan pertama kehidupan ${ }^{14}$. Pada tingkat Nasional, cakupan tersebut juga belum mencapai target yaitu $29,5 \%{ }^{17}$, hal yang sama di tingkat Provinsi Jawa Timur cakupan sebesar 74\% (target 77\%), serta Kabupaten Jember juga masih belum mencapai target (80\%) yaitu $69,43 \%$ (Data Primer, 2018). Selisih presentase dari target yaitu $10,57 \%$, dapat disimpulkan masih terdapat masalah pada pemberian ASI eksklusif di Kabupaten Jember, hal ini dapat mempengaruhi pertumbuhan lingkar kepala anak yang juga akan memiliki dampak pada perkembangan mereka.

Lingkar kepala yang lebih kecil (mikrosefali)
mempunyai korelasi kuat dengan gangguan perkembangan kognitif ${ }^{18}$,sehingga penting dilakukan deteksi dini pengukuran lingkar kepala di tahun awal kehidupan yang mencerminkan pertumbuhan dan perkembangan otak anak ${ }^{9,19}$. Berdasarkan hal tersebut, studi ini bertujuan untuk menganalisis hubungan pemberian ASI eksklusif dan status gizi ibu dengan pertumbuhan lingkar kepala bayi.

\section{METODE PENELITIAN}

Desain penelitian ini menggunakan crosssectional selama bulan Maret hingga April 2019 di wilayah Kecamatan Kaliwates Kabupaten Jember Jawa Timur. Subjek adalah bayi berusia 6 bulan. Besar populasi sebesar 147 bayi dan perhitungan rumus besar sampel menggunakan Finite Population dikarenakan populasi tidak banyak, sehingga didapatkan jumlah sampel minimum sebanyak 107 bayi. Perkiraan dropout sebesar $20 \%$, maka besar sampel sebesar 128 bayi dipilih dengan cara purposive sampling. Kriteria inklusi yaitu ibu bersedia menjadi responden, bayi yang diberi ASI, bayi lahir tidak kurang dari 37 minggu dan bayi tidak memiliki riwayat pnemonia, HIV dan TBC serta terdapat trauma kepala.

Pengambilan data pemberian ASI eksklusif menggunakan metode tanya jawab dan melihat data KMS. Pemberian ASI eksklusif dikategorikan menjadi 2 yaitu 1) Ya, jika ASI diberikan secara eksklusif dimulai dari lahir hingga 6 bulan tanpa MP ASI dan/atau pengganti ASI; 2) Tidak, jika ASI tidak diberikan secara eksklusif sampai 6 bulan, dengan penambahan MP ASI dan/atau pengganti ASI. Data status gizi ibu dengan metode pengukuran langsung berdasarkan IMT yaitu 1) untuk kategori normal adalah gizi normal (18,5 -25 $\left.\mathrm{kgBB} / \mathrm{m}^{2} \mathrm{~TB}\right), 2$ ) kategori tidak normal adalah gizi kurus $\left(<18,5 \mathrm{kgBB} / \mathrm{m}^{2} \mathrm{~TB}\right)$ dan gizi gemuk ( $\left.>25 \mathrm{kgBB} / \mathrm{m}^{2} \mathrm{~TB}\right)$. Data pengukuran lingkar kepala bayi menggunakan ukuran lingkar kepala dengan hasil satuan $\mathrm{cm}$, kemudian diintepretasikan menggunakan grafik pertumbuhan lingkar kepala sesuai jenis kelamin bayi berdasarkan WHO (2007). Lingkar kepala bayi dikategorikan menjadi mikrosefali (<-2SD) dan normal (-2SD - (+2SD)).

Keseluruhan data akan dianalisis menggunakan SPSS dengan uji Chi-square. Terdapat perizinan etik yang telah disetujui oleh Komisi Etik Penelitian Kesehatan Universitas Sebelas Maret No.410/UN27.6/KEPK/2019.

\section{HASIL DAN PEMBAHASAN}

Penelitian ini dilakukan kepada ibu yang memiliki bayi usia 6 bulan. Berdasarkan jenis kelamin bayi, sebagian besar berjenis kelmain laki-laki $(53,9 \%)$. Berdasarkan usia ibu, sebagian besar kelompok usia ibu antara 25-35 tahun $(74,4 \%)$. Pendidikan ibu dan ayah sebagian tamatan SMA/sederajat $(67,2 \%)$. Ibu bayi sebagian besar sebagai IRT $(78,9 \%)$ dan pekerjaan ayah sebagian besar pegawai swasta $(57,8 \%)$. Penghasilan ibu sebagian besar tidak memiliki penghasilan $76,6 \%$ dan penghasilan ayah sebagian besar masih di bawah UMK $(55,5 \%)$. Gambaran karateristik orang tua dan bayi disajikan di Tabel 1. 
Tabel 1. Karateristik Responden

\begin{tabular}{|c|c|c|c|}
\hline Variabel & Kategori & Jumlah & $\%$ \\
\hline \multirow[t]{2}{*}{ Jenis Kelamin } & - Laki-laki & 69 & 53,9 \\
\hline & Perempuan & 59 & 46,1 \\
\hline \multirow[t]{2}{*}{ Usia ibu (tahun) } & $-\quad<25$ & 20 & 25,6 \\
\hline & $-\quad 25-35$ & 108 & 74,4 \\
\hline \multirow[t]{5}{*}{ Pendidikan Ibu } & - $\quad$ Tidak tamat SD & 0 & 0,0 \\
\hline & - Tamat SD/Sederajat & 12 & 9,4 \\
\hline & - Tamat SMP/Sederajat & 7 & 5,5 \\
\hline & - Tamat SMA/Sederajat & 86 & 67,2 \\
\hline & - Perguruan Tinggi & 23 & 18,0 \\
\hline \multirow[t]{5}{*}{ Pekerjaan Ibu } & - $\quad$ PNS/POLRI/TNI & 2 & 1,6 \\
\hline & - Pegawai swasta & 1 & 0,8 \\
\hline & - Wiraswasta & 24 & 18,8 \\
\hline & - Petani/nelayan & 0 & 0,0 \\
\hline & - Lainnya : IRT & 101 & 78,9 \\
\hline \multirow[t]{4}{*}{ Pendapatan Ibu } & - Tidak berpenghasilan & 98 & 76,6 \\
\hline & - $\quad$ > Rp 2.170.918 (UMK) & 4 & 3,1 \\
\hline & - $\quad=\operatorname{Rp} 2.170 .918$ (UMK) & 3 & 2,3 \\
\hline & - $\quad$ < Rp 2.170.918 (UMK) & 23 & 18,0 \\
\hline \multirow[t]{5}{*}{ Pendidikan Ayah } & - Tidak tamat SD & 1 & 0,8 \\
\hline & - Tamat SD/Sederajat & 4 & 3,1 \\
\hline & - Tamat SMP/Sederajat & 6 & 4,7 \\
\hline & - Tamat SMA/Sederajat & 91 & 71,1 \\
\hline & - Perguruan Tinggi & 26 & 20,3 \\
\hline \multirow[t]{5}{*}{ Pekerjaan Ayah } & - $\quad$ PNS/POLRI/TNI & 5 & 3,9 \\
\hline & - Pegawai swasta & 74 & 57,8 \\
\hline & - Wiraswasta & 25 & 19,5 \\
\hline & - Petani/nelayan & 1 & 0,8 \\
\hline & - Lainnya : serabutan & 23 & 18,0 \\
\hline \multirow[t]{4}{*}{ Pendapatan Ayah } & - Tidak berpenghasilan & 0 & 0,0 \\
\hline & - $\quad$ > Rp 2.170.918 (UMK) & 23 & 18,0 \\
\hline & - $\quad=$ Rp 2.170 .918 (UMK) & 34 & 26,6 \\
\hline & - $\quad$ < Rp 2.170.918 (UMK) & 71 & 55,5 \\
\hline
\end{tabular}

Hasil distribusi frekuensi karateristik subjek didapatkan hasil sebagai berikut : 1) Pada pemberian ASI sebagian besar bayi diberikan secara eksklusif $(71,1 \%)$ dibandingkan tidak eksklusif (28,9\%). 2) Pada status gizi ibu sebagian besar ibu berstatus gizi normal $(75,8 \%)$ dibandingkan status gizi kurang $(7,8 \%)$ dan status gizi gemuk $(16,4 \%), 3)$ Pada lingkar kepala bayi sebagian besar bayi berstatus normal $(76,6 \%)$ dibandingkan bayi berstatus mikrosefali $(23,4 \%)$. (Dapat dilihat pada Tabel 2).

Tabel 2. Distrubusi Frekuensi Karateristik Subjek

\begin{tabular}{llc}
\hline \multicolumn{1}{c}{ Variabel } & Jumlah & $\%$ \\
\hline $\begin{array}{l}\text { Pemberian ASI } \\
\text { eksklusif }\end{array}$ & 91 & 71,1 \\
Ya & 37 & 28,9 \\
Tidak & & \\
Status Gizi Ibu (IMT) & & \\
Kurang & 10 & 7,8 \\
Normal & 97 & 75,8 \\
Gemuk & 21 & 16,4 \\
Lingkar Kepala Bayi & & \\
Normal & 98 & 76,6 \\
Mikrorsefali & 30 & 23,4 \\
\hline
\end{tabular}

Distribusi hubungan pemberian ASI eksklusif dengan pertumbuhan lingkar kepala (Tabel 3). Terdapat hasil yaitu bayi yang diberikan ASI secara eksklusif selama 6 bulan cenderung memiliki lingkar kepala normal. Hasil analisis berdasarkan Chi-Square menunjukkan terdapat hubungan yang bermakna antara pemberian ASI eksklusif dengan pertumbuhan lingkar kepala bayi $(p<0,001)$. Didukung penelitian di Enugu Nigeria yang menjelaskan bahwa terdapat perbedaan signifikan pertumbuhan lingkar kepala dengan pemberian ASI eksklusif dan tidak ASI eksklusif pada bayi berusia 0-6 bulan ${ }^{20}$. Bayi dengan ASI eksklusif memiliki ukuran kepala normal dari pada bayi yang tidak pernah disusui atau menggunakan susu botol pada usia 2 bulan ${ }^{12}$. Pemberian ASI eksklusif selama $\geq 4$ bulan menurunkan resiko defisit pertumbuhan lingkar kepala

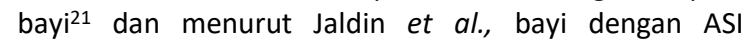
eksklusif terdapat peningkatan ukuran lingkar kepala bayi per bulan yaitu untuk laki-laki rata-rata $1,5 \mathrm{~cm}$ dan perempuan $1,4 \mathrm{~cm}$ pada bayi ${ }^{22}$.

Pada aspek nutrisi, ASI memiliki komposisi nutrisi proposional dan seimbang selama 6 bulan awal kehidupan ${ }^{21}$, oleh sebab itu direkomendasikan pemberian ASI eksklusif selama 6 bulan ${ }^{14}$. Rata-rata kandungan makronutrien dalam ASI yaitu karbohidrat (laktosa) sebesar $8,6 \mathrm{~g} / 100 \mathrm{ml}$, lemak sebesar 2,6 $\mathrm{g} / 100 \mathrm{ml}$ dan protein $1,2 \mathrm{~g} / 100 \mathrm{ml}$ dengan total kalori $61.8 \mathrm{kkal} / 100 \mathrm{ml}^{23}$. Air susu ibu memiliki ketersedian gizi yang lebih baik dalam proses pencernaan, penyerapan, dan metabolisme sel tubuh. 
Tabel 3. Hubungan status gizi ibu dan pemberian ASI eksklusif dengan pertumbuhan lingkar kepala bayi usia 6 bulan

\begin{tabular}{|c|c|c|c|c|c|c|c|}
\hline \multirow{3}{*}{ Variabel } & \multirow{3}{*}{ Kategori } & \multicolumn{4}{|c|}{ Lingkar Kepala } & \multirow{3}{*}{$\mathbf{p}$} & \multirow{3}{*}{ OR } \\
\hline & & \multicolumn{2}{|c|}{ Normal } & \multicolumn{2}{|c|}{ Mikrosefali } & & \\
\hline & & $\mathbf{n}$ & $\%$ & $\mathrm{n}$ & $\%$ & & \\
\hline \multirow{2}{*}{ Pemberian ASI Eksklusif } & ASI eksklusif & 81 & 89,0 & 10 & 11,0 & \multirow{2}{*}{0,000} & \multirow{2}{*}{9,53} \\
\hline & Tidak ASI eksklusif & 17 & 45,9 & 20 & 54,1 & & \\
\hline \multirow{2}{*}{ Status Gizi } & Normal & 70 & 72,2 & 27 & 27,8 & \multirow{2}{*}{0,028} & \multirow{2}{*}{0,28} \\
\hline & Tidak Normal & 28 & 90,3 & 3 & 9,7 & & \\
\hline
\end{tabular}

\begin{abstract}
Kandungan omega-3 dan omega- 6 yang merupakan asam lemak khususnya asam dokosaheksaenoat (DHA), diketahui memainkan peran penting dalam perkembangan otak. Asupan dalam kehamilan dan kehidupan awal bayi mempengaruhi pertumbuhan dan kinerja kognitif di masa kanakkanak $^{24}$. Asupan makan ibu sangat mempengaruhi komposisi zat gizi dalam ASI25, oleh karena itu sangat penting dilakukan diet seimbang untuk ibu menyusui yang bertujuan menyediakan kebutuhan fisiologis ibu dan juga kesehatan bayi melalui kandungan ASI yang ideal $^{26}$.
\end{abstract}

Distribusi pada status gizi dengan pertumbuhan lingkar kepala menunjukkan bahwa ibu berstatus gizi normal cenderung memiliki bayi dengan status lingkar kepala normal (Tabel 3). Hasil analisis berdasarkan Chi-Square menunjukkan terdapat hubungan bermakna antara status gizi ibu dengan pertumbuhan lingkar kepala bayi $(p=0,028)$. Didukung beberapa penelitian yang menjelaskan bahawa status gizi ibu akan menentukan kuantitas dan kualitas produk susu yang secara tidak langsung berperan dalam menentukan status gizi anak ${ }^{15,16}$. Dibuktikan pada penelitian di Kupang bahwa status gizi ibu menyusui berpengaruh secara signifikan terhadap pertumbuhan bayi ${ }^{27}$. Semakin rendahnya status gizi ibu menyusui maka akan mengalami penurunan kinerja laktasi yang akan mengakibatkan peningkatan resiko kematian anak ${ }^{28}$.

Penelitian di Bogor menunjukkan bahwa IMT rendah pada ibu memiliki resiko tidak berhasil menyusui sebesar 2,26-2,56 kali dari pada ibu menyusui IMT normal ${ }^{29}$. Tidak hanya IMT rendah namun ibu dengan IMT lebih akan berdampak negatif pada inisiasi dan durasi menyusui ${ }^{30}$. Penelitian di Shiraz menjelaskan bahwa terdapat hubungan bermakna antara durasi yang lebih pendek terhadap menyusui dengan ibu berstatus gizi lebih ${ }^{31}$. Hasil tersebut secara signifikan dikarenakan ibu memiliki kekhawatiran citra tubuh yang mengakibatkan kurang percaya diri atas kelebihan berat badan yang dimiliki, sehingga BMI dan kekhawatiran citra tubuh yang lebih besar berkaitan dengan durasi menyusui yang lebih pendek ${ }^{32}$. Terdapat sebagian besar ibu dengan obesitas yang memiliki niat menyusui secara eksklusif dan lebih dari $85 \%$ berniat menyusui eksklusif selama 3 bulan namun hanya sebesar 45,3\% ibu menyusui ASI eksklusif selama 3 bulan dan hanya $24,9 \%$ ASI eksklusif selama 5 bulan $^{33}$. Menurut Babendure et al., keterlambatan onset laktogenesis II dan ketidakseimbangan hormon dan adipokin merupakan faktor yang mempengaruhi penurunan tingkat menyusui pada wanita gemuk, sehingga penting untuk menjaga status gizi ibu agar anak tumbuh dengan optimal ${ }^{34}$.

Lingkar kepala merupakan indikator antropometri sensitif dari malnutrisi berkepanjangan selama masa bayi, sehingga lingkar kepala digunakan sebagai ukuran kegagalan pertumbuhan ${ }^{35}$. Bayi yang memiliki lingkar kepala kecil (mikrosefali) memiliki hubungan yang signifikan dengan berat badan rendah, stunting dan wasting ${ }^{36}$. Mikrosefali juga berikatan dengan IQ rendah dan masalah belajar ${ }^{37}$. IQ yang rendah dikaitkan dengan mortalitas yang lebih tinggi38. Masa kanak-kanak yang memiliki nilai IQ rendah akan mulai mempengaruhi resiko kematian pada di pertengahan usia rata-rata manusia ${ }^{4}$. Anak usia dini merupakan fondasi kehidupan di masa depan ${ }^{1}$. Mencegah terjadinya keparahan lanjut seperti perkembangan otak, perkembangan kognitif, masalah belajar dan gizi yang sangat berhubungan dengan lingkar kepala, makan sangat dianjurkan untuk melakukan pemantauan rutin untuk mencapai pertumbuhan fisik yang optimal ${ }^{39}$.

Kelemahan dari penelitian ini diantaranya yaitu variabel yang digunakan belum mewakili semua faktor-faktor yang mempengaruhi pertumbuhan lingkar kepala.

\section{KESIMPULAN}

Pemberian ASI eksklusif selama 6 bulan dan status gizi ibu berhubungan dengan pertumbuhan lingkar kepala bayi. Bagi petugas kesehatan disarankan untuk menjadikan pengukuran lingkar kepala sebagai media pemantauan pertumbuhan karena masih jarang digunakan dan diharapkan melakukan pemantauan secara berkala hingga 2 tahun untuk mencapai potensi pertumbuhan fisik yang optimal dan mencegah terjadinya masalah kurang gizi yang berkepanjangan, selain itu memberikan promosis ASI eksklusif serta pendidikan gizi agar para ibu dapat mempertahankan berat badan optimal yang akan berkontibusi pada kesehatan ibu dan anak-anak mereka.

\section{ACKNOWLEDGEMENT}

Terimaksih untuk Dinas Kesehatan dan Puskesmas Kaliwates Kabupaten Jember yang telah memberikan izin penelitian serta dosen Pascasarjana IImu Gizi UNS yang membimbing penulis sehingga dapat menyelesaikan artikel ini.

\section{REFERENS|}

1. Banerjee, A. \& Chattopadhyay, N. Impact of malnutrition on neuro-development in children from a marginalized rural community in India. Int. J. Sci. Res. 8, (2019).

2. Tiwari, K. et al. Impact of malnutrition on head size and development quotient. Int I Res Med Sci. 5, 3003-3006 (2017). 
3. Yer, W. I. D. E. M. Small, Large, or Abnormally Shape Head. in Current Management in Child Neurology, Third Edition (ed. BL, M.) 338-341 (2005).

4. Jokela, M., Batty, G. D., Deary, I. J., Gale, C. R. \& Kivimäki, M. Low childhood IQ and early adult mortality: the role of explanatory factors in the 1958 British Birth Cohort. Pediatrics. 124, e380-e388 (2009).

5. Veena, S. R. et al. Association of birthweight and head circumference at birth to cognitive performance in 9-to 10-year-old children in South India: prospective birth cohort study. Pediatr. Res. 67, 424 (2010).

6. Sindhu, K. N. et al. Low head circumference during early childhood and its predictors in a semi-urban settlement of Vellore, Southern India. BMC Pediatr. 19, 182 (2019).

7. James, H. E., Perszyk, A. A., MacGregor, T. L. \& Aldana, P. R. The value of head circumference measurements after 36 months of age: a clinical report and review of practice patterns. J. Neurosurg. Pediatr. 16, 186-194 (2015).

8. Maiti, S., Ali, K., Ghosh, D. \& Paul, S. Assessment of head circumference among pre-school children of Midnapore town, West Bengal using WHO (2007) recommended cut-off points. Int J Prev Med. 3, 742-744 (2012).

9. Moll A, Bouthoorn SH, Lenthe FJV, Hokkenkoelega, Anita CS, Tiemeier H, H. A. Head circumference of infants born to mothers with different educational levels : The Generation R Study. PLoS One 7, 1-9 (2012).

10. Hardinsyah \& Supariasa, I. D. N. IImu Gizi Teori Dan Aplikasi. (EGC, 2016).

11. Uwaezuoke, S. N., Eneh, C. I. \& Ndu, I. K. Relationship between exclusive breastfeeding and lower risk of childhood obesity: a narrative review of published evidence. Clin. Med. Insights Pediatr. 11, 1179556517690196 (2017).

12. Herba, C. M. et al. Breastfeeding and early brain development: the $\mathrm{G}$ eneration R study. Matern. Child Nutr. 9, 332-349 (2013).

13. Victora, C. G. et al. Breastfeeding in the 21st century: epidemiology, mechanisms, and lifelong effect. Lancet. 387, 475-490 (2016).

14. WHO. Breastfedding. Switzeland. (WHO,2018).

15. Nadimin, Baharudin, A. \& Zakaria, A. Faktorfaktor yang berhubungan dengan status gizi ibu menyusui wilayah kerja Puskesmas Moncobalang Kabupaten Gowa. Media Gizi Pangan 9, 52-57 (2010).

16. Syafiq, A., Fikawati, S. \& Karima, K. Gizi Ibu Dan Bayi. (PT. Grafindo Indonesia, 2015).

17. Kemenkes, R. Profil Kesehatan Indonesia Tahun 2016. (Kementerian Kesehatan Republik Indonesia, 2017).

18. Maharani, V. Perbandingan Fungsi Kognitif Pada Anak Dengan Gangguan Gizi Dan Anak Dengan Gizi Normal. (Universitas Indonesia, 2015).

19. Andriani, M. \& Wirjatmadi, B. Peran Gizi Dalam Siklus Kehidupan. (Kencana Prenada Media Group, 2012).
20. Chika, N., Odinakachukwu, N., Eucharia, U. \& Aloysius, M. Nutritional assessment of exclusively breastfed and non-exclusively breastfed infants aged (0--6 months) at mother of Christ Specialist Hospital, Enugu, Nigeria. Int J Nutr Food Sci. 3, 462-470 (2014).

21. Ferreira, H. da S., Xavier Junior, A. F. S., de Assuncao, M. L., dos Santos, E. A. \& Horta, B. L. Effect of breastfeeding on head circumference of children from impoverished communities. Breastfeed. Med. 8, 294-301 (2013).

22. Jaldin, M. da G. M., Pinheiro, F. S., Santos, A. M. dos, Muniz, N. C. \& Brito, L. M. O. Head circumference growth of exclusively breastfed infants during the first six months of life. Rev. Paul. Pediatr. 29, 509-514 (2011).

23. Prentice, P. et al. Breast milk nutrient content and infancy growth. Acta Paediatr. 105, 641647 (2016).

24. Huffman, S. L., Harika, R. K., Eilander, A. \& Osendarp, S. J. M. Essential fats: how do they affect growth and development of infants and young children in developing countries? A literature review. Matern. Child Nutr. 7, 44-65 (2011).

25. Erick, M. Nutrition In Pregnancy And Lactation, In Krause'e Food And The Nutrition Care Process. (Elsevier, 2012).

26. Selimouglu, M. A. Importance of nutrition in lactating mothers in terms of both the mother's and the infant's health. Turk Arch Ped 48, 183187 (2013)

27. Soi, B., Julia, M. \& Budiningsari, R. D. Pengaruh status gizi ibu menyusui terhadap eksklusivitas pemberian ASI dan pertumbuhan bayi di RSUD Prof. Dr. WZ. Johannes Kupang. J. Gizi Klin. Indones. 2, 101-107 (2006).

28. Demissie, T., Mekonen, Y. \& Haider, J. Agroecological comparison of levels and correlates of nutritional status of women. Ethiop. J. Heal. Dev. 17, 189-196 (2003).

29. Irawati, A., Triwinarto, A., Salimar, S. \& Raswanti, I. Pengaruh status gizi ibu selama kehamilan dan menyusui terhadap keberhasilan pemberian air susu ibu. Penelit. Gizi dan Makanan (The J. Nutr. Food Res. 26, (2003).

30. Wojcicki, J. M. Maternal prepregnancy body mass index and initiation and duration of breastfeeding: a review of the literature. J. Women's Heal. 20, 341-347 (2011).

31. Soltanian, M. \& Nikouee, F. The Relationship between Duration of Breastfeeding and Mother's BMI. J. Fasa Univ. Med. Sci. 6, 409415 (2016).

32. Hauff, L. E. \& Demerath, E. W. Body image concerns and reduced breastfeeding duration in primiparous overweight and obese women. Am. J. Hum. Biol. 24, 339-349 (2012).

33. Perrine, C. G., Scanlon, K. S., Li, R., Odom, E. \& Grummer-Strawn, L. M. Baby-friendly hospital practices and meeting exclusive breastfeeding intention. Pediatrics 130, 54-60 (2012).

34. Babendure, J. B., Reifsnider, E., Mendias, E., 
Moramarco, M. W. \& Davila, Y. R. Reduced breastfeeding rates among obese mothers: a review of contributing factors, clinical considerations and future directions. Int. Breastfeed. J. 10, 21 (2015).

35. Ivanovic, D. M. et al. Nutritional status, brain development and scholastic achievement of Chilean high-school graduates from high and low intellectual quotient and socio-economic status. Br. J. Nutr. 87, 81-92 (2002).

36. Olusanya, B. O. Pattern of head growth and nutritional status of microcephalic infants at early postnatal assessment in a low-income country. Niger. J. Clin. Pract. 15, 142-146
(2012).

37. Ivanovic, D. M. et al. Head size and intelligence, learning, nutritional status and brain development: head, $I Q$, learning, nutrition and brain. Neuropsychologia. 42, 1118-1131 (2004).

38. Bratsberg, B. \& Rogeberg, O. Childhood socioeconomic status does not explain the IQmortality gradient. Intelligence. 62, 148-154 (2017).

39. Lata Tigga, P., Nitish, M. \& Sen, J. Head circumference as an indicator of undernutrition among tribal pre-school children aged 2-5 years of North Bengal, India. Hum. Biol. Rev. 5, 17-33 (2016). 